\title{
Chemical and Biological Investigations of Leaves of Abroma augusta Linn.
}

\section{S. M. Ashikur Rahman, Muhammed Mahfuzur Rahman, Md. Aslam Hossain and Mohammad A. Rashid}

Phytochemical Research Laboratory, Department of Pharmaceutical Chemistry, Faculty of Pharmacy, University of Dhaka, Dhaka-1000, Bangladesh

Received: May 28, 2016; Accepted: June 25, 2016; Published (Web): July 31, 2016

\begin{abstract}
Abroma augusta Linn. (Family- Sterculiaceae), commonly known as Ulatkambal in Bengali and Hindi, is an evergreen tree widely distributed (native or cultivated) throughout the warm area of India such as Uttar Pradesh, Sikkim, Khasi Hills, Assam and in Bangladesh throughout the hilly regions of Sylhet. It is also found in Java, Philippines and China (Ahmad et al., 2003). A. augusta has a long history of medicinal uses in the Ayurvedic system. It regulates the menstrual flow and also used as abortifacient and anti-fertility agents. In India, it is used in dysmenorrhea but in Indonesia it is used as anti-scabies, anti-dermatitis, antiinflammatory and analgesic agents. The leaves and stems of $A$. augusta are used by the traditional healers of Bogra district of Bangladesh, but the roots are used in Jessore district (Hossan et al., 2010). The plant is being used as a uterine tonic and to treat amenorrhoea. Leaves are useful in the treatment of uterine disorder, diabetes, rheumatic pains and headache with sinusitis. Leaves and stem are used as demulcent. An infusion of fresh leaves and stems in cold water is very efficacious in gonorrhea. The root-bark is used as emmenagogue and uterine tonic (Gupta et al., 2011; Das et al., 2012).
\end{abstract}

Literature survey has revealed a number of chemical and biological investigations of A. augusta (Halim et al., 2001; Laizumanet al., 2010; Sutapa et al., 2012; Uddin et al., 2012; Nahar et al., 1994; Jayaprakasam et al., 2015). As a part of our continuing investigations with medicinal plants of Bangladesh (Jahan et al., 2010), the present study was undertaken to comprehensively conduct the chemical and biological investigations of leaves of A. augusta. We, herein, report beta-sitosterol, stigmasterol and lupeol from the leaf extract. The antioxidant, cytotoxic, thrombolytic and membrane stabilizing activities of the leaves are also reported here.

${ }^{1} \mathrm{H}-\mathrm{NMR}$ spectra were recorded using a Bruker AMX-500 (500 MHz) instrument and the spectra were referenced to the residual non deuterated solvent signal. PTLC $(20 \times 20 \mathrm{~cm})$ and TLC $(20 \times 5 \mathrm{~cm})$ were carried out using Merck $\mathrm{Si}$ gel $\mathrm{PF}_{254}$ on glass plate at a thickness of $0.5 \mathrm{~mm}$. Spots on TLC and PTLC plates were visualized by spraying the developed plates with vanillin-sulfuric acid solution (1:100) followed by heating for 5 minutes at $110^{\circ} \mathrm{C}$. All solvents used in this study were of reagent grade. The standard compounds were collected from the Phytochemical Research Laboratory of the Department of Pharmaceutical Chemistry, University of Dhaka, Dhaka-1000, Bangladesh. The reference standards for the biological investigations were collected form Incepta Pharmaceuticals Ltd., Dhaka, Bangladesh.

The leaves of A. augusta were collected from Sylhet, Bangladesh. The plant was identified at Bangladesh National Herbarium, where a voucher specimen has been deposited for this collection (DACB accession number: 37591).The leaves were dried under sun light for several days and then oven dried for 24 hours at considerably low temperature (not more than $40^{\circ} \mathrm{C}$ ) for better grinding.

The leaf-powder (1200 gm) was taken in a clean, amber color reagent bottle (5 liters) and soaked in $3.0 \mathrm{~L}$ of methanol. The container with its content was sealed by bottle cap and kept for 10 days accompanying occasional shaking and stirring. The mixture was then filtered through a fresh cotton plug and finally with

Correspondence to: Md. Aslam Hossain;; Tel.: +880-2-9661900, extn. 8152; E-mail: aslamsaga@ yahoo.com 
Whatman Number 1 filter paper. The filtrate was allowed to dry to yield the crude extract. Solventsolvent partitioning was done using the modified Kupchan method (Van Wagenen et al., 1993). A portion of the crude extract $(5 \mathrm{gm})$ was dissolved in $10 \%$ aqueous methanol and extracted with petroleum ether, then with carbon tetrachloride followed by chloroform and finally with water to provide petroleum ether soluble fraction (PESF), carbon tetrachloride soluble fraction (CTSF), chloroform soluble fraction (CSF) and aqueous soluble fraction (AQSF), respectively. Later on, the fractions were allowed to concentrate.

The CTSF was subjected to purification by column chromatography packed with silica gel (Kieselgel 60, mesh 70-230). Slurry of silica gel in petroleum ether was added into a glass column having the length and diameter of $55 \mathrm{~cm}$ and $1.1 \mathrm{~cm}$, respectively. The column was then eluted with petroleum ether, followed by mixtures of petroleum ether and ethyl acetate of increasing polarity, then by ethyl acetate and finally with ethyl acetate and methanol mixtures of increasing polarity. Total 184 fractions (about $20 \mathrm{ml}$ each) were collected.

$\beta$-sitosterol (3.0 $\mathrm{mg})$ was obtained as white amorphous powder through preparative TLC using solvent system toluene and ethyl acetate (99:1) of column fractions $71-77$ whereas stigmasterol $(2.6 \mathrm{mg})$ was isolated from column fractions $81-83$ as needle shaped crystalline mass. On the other hand, preparative TLC of the fractions 56-58 using mixture of toluene and ethyl acetate (98:2) yielded lupeol $(2.7 \mathrm{mg})$.

$\beta$-sitosterol: whitish amorphous powder, ${ }^{1} \mathrm{H}-\mathrm{NMR}$ $\left(\mathrm{CDCl}_{3}, 500 \mathrm{MHz}\right): \delta 5.35(1 \mathrm{H}, \mathrm{m}, J=6.0 \mathrm{~Hz}, \mathrm{H}-6)$, 3.52 (1H, m, H-3), 1.01 (3H, s, Me-19), 0.93 (3H, d, $J=$ $6.5 \mathrm{~Hz}, \mathrm{Me}-21), 0.85$ (3H, t, $J=7.8 \mathrm{~Hz}, \mathrm{Me}-29), 0.83$ $(3 \mathrm{H}, \mathrm{d}, J=7.5 \mathrm{~Hz}, \mathrm{Me}-26), 0.82(3 \mathrm{H}, \mathrm{d}, J=7.5 \mathrm{~Hz}, \mathrm{Me}-$ 27), 0.69 (3H, s, Me-18).

Stigmasterol: colorless needle shaped crystals; ${ }^{1} \mathrm{H}-$ NMR $\left(\mathrm{CDCl}_{3}, 500 \mathrm{MHz}\right): \delta 5.34(1 \mathrm{H}, \mathrm{m}, \mathrm{Hz}, \mathrm{H}-6), 5.15$ $(1 \mathrm{H}, \mathrm{dd}, J=6.5,15.0 \mathrm{~Hz}, \mathrm{H}-22), 5.02(1 \mathrm{H}, \mathrm{dd}, J=9.0$, $15.0 \mathrm{~Hz}, \mathrm{H}-23), 3.51(1 \mathrm{H}, \mathrm{m}, \mathrm{H}-3 \alpha), 1.00(3 \mathrm{H}$, br. s, Me-19), 0.91 (3H, d, $J=6.5 \mathrm{~Hz}, \mathrm{Me}-21), 0.83(3 \mathrm{H}, \mathrm{d}$, $J=7.0 \mathrm{~Hz}, \mathrm{Me}-26), 0.81$ (3H, d, $J=4.5 \mathrm{~Hz}, \mathrm{Me}-27)$, 0.80 (3H, t, $J=7.8 \mathrm{~Hz}, \mathrm{Me}-29), 0.67$ (3H, br. s, Me-18).
Lupeol: ${ }^{1} \mathrm{H}-\mathrm{NMR}\left(500 \mathrm{MHz}, \mathrm{CDCl}_{3}\right): \delta 4.70(1 \mathrm{H}$, br. s, $\left.\mathrm{H}_{\mathrm{a}}-29\right), 4.65\left(1 \mathrm{H}\right.$, br. $\left.\mathrm{s}, \mathrm{H}_{\mathrm{b}}-29\right), 3.20(1 \mathrm{H}, \mathrm{m}, \mathrm{H}-$ 3), $2.12(1 \mathrm{H}, \mathrm{m}, \mathrm{H}-19), 1.67$ ( $\left.3 \mathrm{H}, \mathrm{s}, \mathrm{H}_{3}-30\right), 1.02$ (3H, s, $\left.\mathrm{H}_{3}-26\right), 0.96$ ( $\left.3 \mathrm{H}, \mathrm{s}, \mathrm{H}_{3}-23\right), 0.92$ (3H, s, $\left.\mathrm{H}_{3}-27\right), 0.87$ (3H, s, $\left.\mathrm{H}_{3}-25\right), 0.81$ (3H, s, $\left.\mathrm{H}_{3}-28\right), 0.79$ (3H, s, $\left.\mathrm{H}_{3}-24\right)$.

Total phenolic content of extractives leaves of $A$. augusta was measured employing the method of Skerget et al., (2005) involving Folin-Ciocalteu reagent as oxidizing agent and gallic acid as standard (Majhenic et al., 2007).

Following the method of Meyer et al., (1982) the cytotoxic properties of the extractives of the leaves of A.augustawas determined against Artemia salinain an one-day in vivo assay. Vincristine sulfate was used as positive control.

The thombolytic activity of the crude extract and partitionates was assessed by the method developed by Prasad et al., (2007).

According to the method developed by Shinde et al. (1999) and modified method by Sikder et al. (2011), the membrane stabilizing activity of the extractives was determined by evaluating their ability to prevent hypotonic solution- and heat-induced hemolysis of human erythrocyte.

Chromatrographic separation and purification of soluble fraction of methanolic extract of A. augusta led to the isolation of two phytosterols identified as $\beta$ sitosterol and a stigmasterol and a triterpene- lupeol which were characterized by analysis of ${ }^{1} \mathrm{H}-\mathrm{NMR}$ spectral data and comparison with reported values. The identity of each compound was further substantiated by co-TLC with authentic samples.

The methanol extract and its different fractions were investigated to determine total phenolic content by Folin-Ciocalteau reagent, cytotoxicity by brine shrimp lethality, thrombolytic and membrane stabilizing activities.

The amount of total phenolic content differed in different extractives and ranged from $50.58-266.38 \mathrm{mg}$ of gallic acid equivalent (GAE)/gm of extractives. Among all extractives of leaves of A. augusta, the highest phenolic contentwas found in chloroform soluble fraction (266.38 $\mathrm{mg}$ of GAE/gm of extractives) which is followed by petroleum ether soluble fraction (251.81 mg of GAE/gm of extractives) (Table 1). 
In brine shrimp lethality bioassay, vincristine sulfate (VS) was used as positive control and the $\mathrm{LC}_{50}$ was found to be $0.45 \mu \mathrm{g} / \mathrm{ml}$. Among the extractives, the chloroform soluble fraction demonstrated most significant cytotoxic activity as evident from the $\mathrm{LC}_{50}$ value of $2.69 \mu \mathrm{g} / \mathrm{ml}$ (Table 1).

Table 1. Total phenolic content, cytotoxicity, thrombolytic and membrane stabilizing activities of leaves of $\mathrm{A}$. augusta.

\begin{tabular}{lccccc}
\hline Sample & $\begin{array}{c}\text { Total phenolic } \\
\text { content (mg of } \\
\text { GAE/ gm of } \\
\text { dried extract) }\end{array}$ & $\begin{array}{c}\text { Brine shrimp } \\
\text { lethality } \\
\text { bioassay LC50 } \\
(\mu \mathrm{g} / \mathrm{ml})\end{array}$ & $\begin{array}{c}\text { Thrombolytic } \\
\text { activity (in } \\
\text { terms of } \% \text { of } \\
\text { clot lysis) }\end{array}$ & $\begin{array}{c}\text { \% inhibition of haemolysis } \\
\text { (hypotonic solution- } \\
\text { induced) }\end{array}$ & $\begin{array}{c}\text { \% inhibition of } \\
\text { haemolysis } \\
\text { (heat-induced) }\end{array}$ \\
\hline VS & - & 0.45 & - & - & - \\
ME & 86.63 & 6.86 & 32.87 & 76.43 & 45.36 \\
PESF & 251.81 & 10.09 & 32.39 & 85.83 & 51.18 \\
CTSF & 183.30 & 3.20 & 44.90 & 66.45 & 22.45 \\
CSF & 266.38 & 2.69 & 11.23 & 87.50 & 10.71 \\
AQSF & 50.58 & 15.83 & 41.51 & 95.22 & 23.44 \\
Blank & - & - & 10.27 & - & - \\
Streptokinase & - & - & 66.77 & - & - \\
ASA & - & - & - & 71.91 & 42.20 \\
\hline
\end{tabular}

$\mathrm{ME}=$ Methanol crude extract; $\mathrm{PESF}=\mathrm{Petroleum}$ ether soluble fraction; $\mathrm{CTSF}=\mathrm{Carbon}$ tetrachloride soluble fraction; $\mathrm{CSF}=$ Chloroform soluble fraction and $\mathrm{AQSF}=$ Aqueous soluble fraction; $\mathrm{BHT}=$ Butylated hydroxytolune; VS= Vincristine sulfate; ASA= Acetylsalicylic acid.

In order to discover cardio protective drugs from natural sources, the crude extract and its different fractions were assessed for thrombolytic activity and the results are presented in table 1 . Addition of $100 \mu \mathrm{l}$ streptokinase, a positive control (30,000 I.U.), to the clots demonstrated $66.77 \%$ lysis of clot. On the other hand, distilled water was applied as negative control which exhibited $10.27 \%$ lysis of clot (Table 1).

In hypotonic solution-induced condition the aqueous soluble fraction at $1.0 \mathrm{mg} / \mathrm{ml}$ inhibited highest percentage of haemolysis of RBC $(95.22 \%)$ while acetylsalicylic acid $(0.10 \mathrm{mg} / \mathrm{ml})$ showed $71.91 \%$ inhibition. On the other hand, at heat-induced condition the petroleum ether soluble fraction at $1.0 \mathrm{mg} / \mathrm{ml}$ inhibited highest percentage of haemolysis of RBC $(51.18 \%)$ as compared to the standard acetyl salicylic acid $(0.10 \mathrm{mg} / \mathrm{ml})$ displayed by $42.20 \%$ inhibition.

\section{References}

Ahmad, W., Khan, T., Ahmad, B., Iqbal, Z., Ahmad, M., Ahmad, M., Jan, Q. and Arfan M. 2003. Chemical composition of Abroma augusta Linn. seedoil. Pak. J. Biol. Sci. 6, 1033-1034.
Das, S., Datta, R. and Nandy S. 2012. Phytochemical screening and evaluation of anti-inflammatory activity of methanolic extract of Abroma augusta Linn. Asian Pacific J. Trop. Dis. 2(S1), S114-S117.

Gupta, B., Nayak, S. and Solanki, S. 2011. Abroma augusta Linn f: A review. Der Pharmacia Sinica. 2, 253-261.

Hossan, M.S., Hanif, A., Agarwala, B., Sarwar, M.S., Karim, M., Taufiq-Ur-Rahman, M., Jahan , R. and Rahmatullah, M. 2010. Traditional use of medicinal plants in Bangladesh to treat urinary tract infections and sexually transmitted diseases. Ethnobot. Res. Appl. 8, 61-74.

Halim, E., Hussain, M.A., Kaiser, J. and Mala, R. 2001. Preliminary studies on the hypoglycaemic effect of Abroma augusta in alloxan diabetic rats. Indian J. Clin. Biochem. 16, 77-80.

Laizuman, N., Farhana, A.R. 2010. Comparative study of antidiabetic effect of Abromaaugusta and Syzygiumcumini on alloxan induced diabetic rat. Agric. Biol. J. N. Am. 1, 1268-1272.

Sutapa, D., Rana, D., and Subhangkar N. 2012, Phytochemical screening and evaluation of antiinflammatory activity of methanolic extract of Abroma augusta Linn. Asian Pacific J. Trop. Disease, S114S117.

Uddin, M.Z., Dibyajyoti, S., Aninda K.N., Anowara J., Mycal, D. and Swati, P. 2012.Comparative study of antibacterial, antifungal and cytotoxic effects of different extracts of Dillenia indica thunb and Abroma augusta Linn. Bull. Pharm. Res. 2, 124-128. 
Nahar, N., Hazra, B.K., Mosihuzzaman, M., Rahman, M.M. 1994. Structural studies of a mucilage from Abroma augusta root bark. Carb. Polymers 24, 277-280.

Jayaprakasam, R., Philip, N., Vinod, S., Jacob. L. and Thengungal, K.R. 2015. HPTLC method for the simultaneous estimation of stigmasterol and $\beta$-sitosterol in Abroma augusta Linn. roots and itsin vitro biological activity screening. Indian Drugs, 52, 12-19.

Jahan, I., Rahman, M.S., Rahman, M.Z., Kaisar, M. A., Islam M.S., Wahab A., Rashid M.A. 2010. Chemical and biological investigations of Delonix regia (Bojer ex Hook.) Raf. Acta Pharm. 60, 207-215.

Škergeta, M., Kotnik, P., Hadolin, M. ,Hraš, A.R., Simonič, M., Knez, Z. 2005. Phenols, proanthocyanidins, flavones and flavonols in some plant materials and their antioxidant activities. Food Chem. 89, 191-198.

Majhenič, L., Škerget, M. and Kenz, Ž. 2007. Antioxidant and antimicrobial activity of guarana seed extracts. Food Chem. 104, 1258-1268.

Meyer, B.N., Ferringni, N.R., Puam, J.E., Lacobsen, L.B., Nichols, D.E. and McLaughlin, J.L. 1982. Brine shrimp: a convenient general bioassay for active constituents. Planta Med. 45, 31-32.
Prasad, S., Kashyap, R.S., Deopujari, J.Y., Purohit, H.J., Taori, G.M. and Daginawala, H.F. 2007. Effect of Fagonia arabica (Dhamasa) on in vitro thrombolysis, BMC Complement. Alternat. Med. 7, 7-36.

Shinde, U.A., Phadke, A.S., Nair, A.M., Mungantiwar, A.A., Dikshit, V.J. and Saraf, M.N. 1999. Membrane stabilizing activity - a possible mechanism of action for the anti-inflammatory activity of Cedrus deodara wood oil. Fitoterapia 70, 251-257.

Sikder, M.A., Rahman, M.A., Kaisar, M.A., Rahman, M.S., Hasan, C.M. and Rashid, M.A. 2011. In vitro antioxidant, reducing power, free radical scavenging and membrane stabilizing activities of seeds of Syzygium cumini L. Lat. Am. J. Pharm. 30,781-785.

Van,Wagenen, B.C., Larsen, R., Cardellina, II, J.H., Randazzo, D., Lidert, Z.C. and Swithenbank, C. 1993. Ulosantoin, a potent insecticide from the sponge Ulosa ruetzleri. J. Org. Chem. 58, 335-337. 